\title{
A pragmatic approach to delimiting incursions
}

\author{
G.M. Burnip ${ }^{1}$, J.M. Kean² and A.K. Pathan ${ }^{3}$ \\ ${ }^{1}$ Ministry for Primary Industries, PO Box 14028, Christchurch, New Zealand \\ ${ }^{2}$ AgResearch, Private Bag 3115, Hamilton, New Zealand \\ ${ }^{3}$ Ministry for Primary Industries, PO Box 1340, Rotorua, New Zealand \\ Corresponding author: graham.burnip@mpi.govt.nz
}

When incursions of exotic organisms are first detected, Ministry for Primary Industries (MPI) investigators normally assess the spatial extent of populations to evaluate whether eradication is a viable option. However, delimitation of the entire risk area typically requires substantial effort and cost. Collaboration between MPI and Better Border Biosecurity researchers led to the realisation that a quantified geographic distribution of the exotic organism's population is not necessarily required to determine eradication viability. The question is not "where in the landscape is the organism present?" but the more manageable "is the organism present across such a widespread area that eradication is not feasible?" This pragmatic approach focuses on getting the delimitation question right, and narrows the scope of investigative actions to something achievable. This approach informed response option development when the Australian pasture tunnel moth (Philobota sp) incursion was first detected in New Zealand in 2010, and for the eucalyptus leaf beetle (Paropsisterna beata) detected in 2012. Further details of this approach have been published in: Kean JM, Burnip GM, Pathan A 2014. Detection survey design for decision making during biosecurity incursions. In: Jarrad FC, Low-Choy SJ, Mengersen K ed. Biosecurity Surveillance: Quantitative Approaches. ISBN: 9781780643595. CAB International.

\section{Is this imported food compliant with biosecurity regulations?}

\author{
M.A. Novoselov ${ }^{1,3}$, I.I. Iline ${ }^{1,3}$, Z. Sinovcic ${ }^{2,3}$ and C.B. Phillips ${ }^{1,3}$ \\ ${ }^{1}$ AgResearch, Lincoln, Private Bag 4749, Canterbury 8140, New Zealand \\ ${ }^{2}$ Ministry for Primary Industries, PO Box 53066, Auckland 2022, New Zealand \\ ${ }^{3}$ Better Border Biosecurity collaboration (B3) \\ Corresponding author: Maksim.Novoselov@agresearch.co.nz
}

Imported food products can carry biosecurity hazards such as animal, plant and human diseases. To reduce this risk, imported foods that contain ingredients of animal origin must be retorted in compliance with a New Zealand Ministry for Primary Industries (MPI) Import Health Standard. AgResearch and MPI have developed a proof-of-concept enzymatic colorimetric assay (Iline et al. 2013; Proof of concept for a biochemical test that differentiates between heat-treated and non-heat-treated food products, New Zealand Plant Protection 66: 34-39). In April 2014, MPI asked for a test to determine if a tinned food imported from India had been retorted to standard. Using the proof-of-concept assay, all 10 samples showed weak enzyme activity, while control samples heated to the MPI standard produced no enzyme activity. Normally the test detects activity of the enzyme glucose phosphate isomerase (GPI), but additional testing showed that GPI was inactive. A possible source of the activity was a bacterial enzyme. The results suggested the product had not been retorted to the MPI standard. 